\title{
Editorial \\ Research on Hybrid Solar Photovoltaic/Thermal (PV/T) System
}

\author{
Senthilarasu Sundaram ${ }^{1}\left(\mathbb{D}\right.$, Manosh C. Paul $^{2} \mathbb{D}$ and Yasser Mahmoudi $^{3, *}$ \\ 1 Environment and Sustainability Institute, Penryn Campus, University of Exeter, Cornwall TR10 9FE, UK; \\ s.sundaram@exeter.ac.uk \\ 2 James Watt School of Engineering, University of Glasgow, Glasgow G12 8QQ, UK; \\ manosh.paul@glasgow.ac.uk \\ 3 Department of Mechanical, Aerospace and Civil Engineering, The University of Manchester, \\ Manchester M13 9PL, UK \\ * Correspondence: yasser.mahmoudilarimi@manchester.ac.uk
}

Citation: Sundaram, S.; Paul, M.C.; Mahmoudi, Y. Research on Hybrid Solar Photovoltaic/Thermal (PV/T) System. Energies 2022, 15, 886. https://doi.org/10.3390/ en15030886

Received: 27 December 2021

Accepted: 21 January 2022

Published: 26 January 2022

Publisher's Note: MDPI stays neutral with regard to jurisdictional claims in published maps and institutional affiliations.

Copyright: (C) 2022 by the authors. Licensee MDPI, Basel, Switzerland. This article is an open access article distributed under the terms and conditions of the Creative Commons Attribution (CC BY) license (https:// creativecommons.org/licenses/by/ $4.0 /)$.

\section{Introduction}

Modern-day buildings have become the third-largest consumer of energy, after industry and agriculture, and energy consumption in buildings contributes up to $40 \%$ of the total energy use in developed countries. Energy consumption is rapidly increasing with the growth of population, urbanisation, and demands of building services and comfort levels. Thus, reducing building energy consumption plays a very crucial role in controlling global energy demand and mitigating climate change.

A useful measure to reduce building energy use is hybrid photovoltaic/thermal $(\mathrm{PV} / \mathrm{T})$ system. PV/T panels combine two well-established renewable energy technologiessolar photovoltaic modules and solar thermal collectors-into one integrated component that removes generated heat from the solar photovoltaics, thereby improving electrical efficiencies [1,2]. The electrical performance of more recently installed PV/T systems does show an overall increase in the annual electrical energy output of $4-12 \%$ in comparison with solar PV systems in the same situation. Using PV/T the generation potential per square meter can be substantially increased. This is particularly advantageous when space for installation can be limited, such as on domestic roofs. In some systems, it is possible to obtain the same energy output as a side-by-side installation of solar PV and solar thermal in $40 \%$ less area. PV/T systems can also integrate with energy-use equipment, such as heat pumps and absorption chillers, to provide heating or cooling for buildings [1]. Moreover, solar thermal and power technologies can also integrate with distributed energy storage systems and building demand response technologies to improve the flexibility and reliability of both utility grids and buildings.

This Special Issue presents a collection of original articles and case studies focusing on investment economic benefits of solar photovoltaic systems, performance assessment, cooling and temperature control, as well as integration of solar photovoltaic technology with other renewable systems.

\section{Overview of Contributions to the Special Issue}

This Special Issue comprehends four research articles, with the scope investigated being mainly representative of the UK, EU, Korea, and Saudi Arabia. A brief description and discussion of the contributions to this Special Issue are reported in this section. It is worth noting that the order in which the contributions are presented does not imply any judgment of merit, and it is dictated only by narrative purposes.

Solar PV panels are typically 20\% efficient, and a significant fraction of the absorbed sunlight rays are converted into heat. The generated heat increases the temperature of the panel, resulting in a decrease in the electrical efficiency and, consequently, a poor economic scenario. In this regard, Haidar et al. [3] performed comprehensive experimental and modelling studies on the cooling of PV panels using the evaporative cooling (EC) principle. 
A new EC design to cool the bottom surface of a PV panel was fabricated, tested, and modelled, in order to assess the effectiveness of the EC method for solar PVs. A series of experimentation under realistic outdoor conditions was performed in Riyadh, Saudi Arabia, in July. To better understand the cooling process of the PV panel and perform a detailed, parametric study, a steady-state heat and mass transfer model was implemented and compared with the experimental data. The results showed that the uncooled PV panel temperature can reach about $73^{\circ} \mathrm{C}$, while the temperature of the evaporatively cooled panel does not exceed $65^{\circ} \mathrm{C}$ (over $10{ }^{\circ} \mathrm{C}$ cooling using the proposed cooling technique). This results in an average efficiency gain of $6.7 \%$ and power output improvement of $5 \%$. Additionally, they observed that the evaporative cooling reduced the PV temperature fluctuation, which results in better regulation of electrical power output and reduces the uncertainty associated with solar PV systems.

Kim et al. [4] studied building-integrated PVT (BIPVT) systems which can simultaneously produce electricity and heat for buildings that require heating and offer higher solar energy use per unit area of installation than conventional BIPV systems. They designed and built a new air-type PVT collector with perforated baffles and conducted outdoor experimental tests to assess the performance of the proposed system. The tests were performed from April to May 2020, in Cheonan, South Kora, under a radiation intensity of at least $700 \mathrm{~W} / \mathrm{m}^{2}$ on the inclined plane and varying inlet/outlet airflow rates of 100,150 , and $200 \mathrm{~m}^{3} / \mathrm{h}$. They found that the thermal efficiency of the proposed air-type PVT collector was $47 \%$ at an airflow of $200 \mathrm{~m}^{3} / \mathrm{h}$. During peak solar radiation of about $950 \mathrm{~W} / \mathrm{m}^{2}$, the thermal efficiency was between $34.7 \%$ and $49.9 \%$, for the flow rate in the range of $100-200 \mathrm{~m}^{3} / \mathrm{h}$. The electrical efficiency of the system dropped from $16.6 \%$ to $16.1 \%$ when the PV module rear temperature rose from $44{ }^{\circ} \mathrm{C}$ to $52{ }^{\circ} \mathrm{C}$. Under the outside temperature range of $21-31^{\circ} \mathrm{C}$ and radiation of $825-958 \mathrm{~W} / \mathrm{m}^{2}$, the electrical efficiency decreased by $0.375 \%$ for every $1{ }^{\circ} \mathrm{C}$ increase in PV module rear temperature. Their exergy analysis showed that the total exergy efficiency of the air-type PVT collector with perforated baffles is $24.8-30.5 \%$, almost half of the total energy efficiency which is $44.1-63.3 \%$.

Eko and Paul [5] analysed the integration of solar photovoltaic systems with other energy sources in sub-Saharan Africa, Malawi region, in order to address a key research question: "How can the low electricity access rate in Malawi be addressed?" They considered the integration of multiple possible off-grid, integrated, sustainable energy systems based on locally available energy resources including solar photovoltaic, wind turbine, diesel generators, and battery storage. The multiyear and sensitivity analysis function of HOMER Pro microgrid simulation software is used to analyse the off-grid performance of the proposed integrated system, to provide electricity for an estimate of 400 households in Machinga Boma, a community in the southern region of Malawi. They found that among various integrated systems, the system comprising a solar photovoltaic array $(750 \mathrm{kWp})$, a diesel generator $(460 \mathrm{~kW})$, and a $3000 \mathrm{kWh}$ nominal capacity battery bank is the most optimal system, with an overall energy cost of USD $0.339 / \mathrm{kWh}$. Based on the cost simulation result, the lithium-ion battery component accounts for $49 \%$ of the total system initial capital cost of the proposed system. While USD $0.339 / \mathrm{kWh}$ is in line with other studies in the literature, the electricity tariffs in Malawi for residential and non-residential use are USD $0.13 / \mathrm{kWh}$ and USD $0.16 / \mathrm{kWh}$, respectively. This means that the reposed hybrid energy system offers a higher price per kWh of electricity, possibly due to the inclusion of a diesel generator and battery storage in the system. While technically feasible, this highly hybrid system's energy cost poses a constraint on the rate of acceptance of the system by the users, due to the familiarity of a lower cost per kWh (tariff structure) in Malawi. Finally, in comparison with a diesel-generator-only system, their proposed hybrid system is significantly more environmentally benign, producing $\mathrm{CO}_{2}$ of only $10 \%$ of the average $\mathrm{CO}_{2}$ produced by a diesel system. The environmental impact of the system is an essential consideration, especially as the Malawian energy policy goal centres on reducing the dependence on traditional biomass and traditional fuels. 
Using a panel data approach, Tomczak et al. [6] determined whether investing in so-called 'green' companies that are associated with the production of photovoltaic (PV) components offers a greater return on an investment relative to investing in 'red' companies that do not manufacture PV components. They used a sample for the period of 2015-2018 and applied a new approach to panel data for the sector, taking into account 92 ratios derived from balance sheets, profit and loss accounts, cash flow, and market value data. They deployed the classification trees, the k-nearest neighbour methods, and the Altman model to investigate whether companies that manufacture solar modules, solar cells, solar silicon rods, solar wafers, solar power, solar photovoltaic products, and related equipment (green companies) can be differentiated from other enterprises in the sector that are not associated with renewable energy and whether these companies are in a better financial state. Their analysis showed that the green companies can be distinguished from red companies at classification accuracies of $90 \%, 86 \%$, and $93 \%$ for the chi-squared automatic interaction detector (CHAID), classification and regression trees (CRT), and k-nearest neighbour algorithms, respectively. On the basis of an assessment of the financial performance of enterprises using two variants of the Altman model, they conclude that red enterprises perform better financially, compared with green enterprises. Such a finding was in agreement with the recent literature, with studies suggesting that investment in green companies is not lucrative, going green does not increase revenue, and/or that fossil fuel companies tend to perform better financially. However, green enterprises exhibit an upward trend in ratios, as indicated by an analysis of crucial ratios. This finding implies that in the near future, financial indicators for green companies may equal or exceed those of red companies if this upward trend continues. Importantly, this suggests that the profitability of green companies is increasing and, thus, investing in green companies has the potential for profitability.

Funding: This research received no external funding.

Acknowledgments: The Editors are grateful to all authors and reviewers for their outstanding work and support in fulfilling the proposed goal of this Special Issue.

Conflicts of Interest: The authors declare no conflict of interest.

\section{References}

1. Obalanlege, M.A.; Mahmoudi, Y.; Douglas, R.; Bailie, D.; Davidson, J. Experimental assessment of short cycling in a hybrid photovoltaic-thermal heat pump system. Appl. Energy 2020, 268, 114916. [CrossRef]

2. Obalanlege, M.A.; Mahmoudi, Y.; Douglas, R.; Ebrahimnia-Bajestan, E.; Bailie, D.; Davidson, J. Performance assessment of a hybrid photovoltaic-thermal and heat pump system for solar heating and electricity. Renew. Energy 2020, 148, 558-572. [CrossRef]

3. Haidar, Z.A.; Orfi, J.; Kaneesamkandi, Z. Photovoltaic Panels Temperature Regulation Using Evaporative Cooling Principle: Detailed Theoretical and Real Operating Conditions Experimental Approaches. Energies 2021, 14, 145. [CrossRef]

4. Kim, J.-H.; Yu, J.-S.; Kim, J.-T. An Experimental Study on the Energy and Exergy Performance of an Air-Type PVT Collector with Perforated Baffle. Energies 2021, 14, 2919. [CrossRef]

5. Eko, J.O.; Paul, M.C. Integrated Sustainable Energy for Sub-Saharan Africa: A Case Study of Machinga Boma in Malawi. Energies 2021, 14, 6330. [CrossRef]

6. Tomczak, S.K.; Skowrońska-Szmer, A.; Szczygielski, J.J. Is It Possible to Make Money on Investing in Companies Manufacturing Solar Components? A Panel Data Approach. Energies 2021, 14, 3406. [CrossRef] 